\title{
Rouleaux Formation Count
}

National Cancer Institute

\section{Source}

National Cancer Institute. Rouleaux Formation Count. NCI Thesaurus. Code C74624.

The determination of the number of stacking red blood cells present in a blood sample. 